\title{
Hope Mediates the Relation between Income and Subjective Well-Being
}

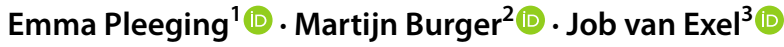 \\ Published online: 5 September 2020 \\ (c) The Author(s) 2020
}

\begin{abstract}
In this study, we examine whether the positive effect of income gains on subjective wellbeing (SWB) can in part be explained by the improved future prospects that are generated by a more solid financial situation. Using three-wave panel data from the US, we inspect the relation between changes in income, hope and SWB using a fixed-effects model. Results show that hope indeed partially mediates the relation between income and SWB, but only for monthly incomes over $\$ 1800$. Positive expectations, on the other hand, mediate the relation for all income levels. From the two components of hope, agency, the belief that we can achieve our goals, seems to be the strongest mediator. We find no indications that extremely high levels of hope or expectations will harm SWB through disappointment.
\end{abstract}

Keywords Hope $\cdot$ Expectations $\cdot$ Aspirations $\cdot$ Subjective well-being $\cdot$ United states

\section{Introduction}

Do favourable life circumstances increase subjective well-being (SWB) because they increase positive expectations for the future? Or, in other words; would positive circumstances, such as a good income, a nice house or good friends, make us happy, if they did not give us the feeling that the future will be positive as well? Intuitively, it seems that we need at least some grounds to believe in a bright future in order to feel happy. People are forward-looking creatures, and very well capable and inclined to form prospects of their future, based on their current situation (Tversky and Kahneman 1979; Snyder2000). If we define SWB as enjoyment of 'life-as-a-whole' (Diener et al. 1999; Veenhoven 2011), this evaluation should be affected by how we expect our future to unfold (Bailey and Snyder 2007).

Emma Pleeging

pleeging@ese.eur.nl

1 Erasmus Happiness Economics Research Organisation, Erasmus University Rotterdam, Burgermeester Oudlaan 50, 3000 DR, Rotterdam, The Netherlands

2 Erasmus Happiness Economics Research Organisation and Department of Applied Economics, Erasmus School of Economics, Erasmus University Rotterdam, Rotterdam, The Netherlands

3 Erasmus School of Health Policy \& Management and Department of Applied Economics, Erasmus School of Economics, Erasmus University Rotterdam, Rotterdam, The Netherlands 
Positive life circumstances generally lead us to expect more of our future, whilst negative circumstances make us more pessimistic (Sweeny et al. 2006; Stutzer 2004; Senik 2008; Foster and Frijters 2014). Hence, we tend to be more hopeful about the future when life is going well at the present. Furthermore, how our circumstances affect SWB seems to depend at least partly on how we perceive our future. That is, negative circumstances can be deemed less detrimental if we expect improvement in the future; negative shocks will have a less profound effect if people are more optimistic; and optimists can cope with stressors more efficiently then pessimists (Scheier and Carver 1992; Clark et al. 2008; Fredrickson 2001; Green 2011; Arampatzi et al. 2020). ${ }^{1}$ This begs the question whether a part of the SWB created by our current circumstances is due to the positive hopes that they engender.

A specific point of interest in this respect, is income; although there appears to be a positive association between income and SWB (see e.g., Clark et al. 2008; Kahneman and Deaton 2010; Stevenson and Wolfers 2013; Jebb et al. 2018), it not one of simple cause and effect, partly due to the many societal and psychological factors that moderate and mediate this relationship (Diener et al. 2013). Although most studies have pointed at increased consumption and status as mechanisms behind the income-SWB relationship (Clark et al. 2008), future expectations could also play an important role in this regard. Previous studies have shown that debt, income expectations and financial security matter strongly for our SWB, arguably even more than our income per se (Brown et al. 2005; Frijters Liu and Meng 2012; Arampatzi et al. 2015). ${ }^{2}$ In addition, our feelings and thoughts about the future seem to be affected by our current financial situation (Sweeny et al. 2006; Stutzer 2004; Senik 2008; Foster and Frijters 2014). Hence, there are reasons to believe that a higher income increases SWB partly because it generates positive expectations of the future.

At the same time, previous studies have shown that overly optimistic financial expectations generally lead to disillusionment once people realize their expectations can't be met in reality, leading them to be unhappier in the long run. In this study, we therefore focus on the slightly different concept of 'hope', defined by Martin (2011, p. 8) as endorsed desire plus uncertainty: "... to hope for an outcome is to desire (be attracted to) it, to assign a probability somewhere between 0 and 1 to it, and to judge that there are sufficient reasons to engage in certain feelings and activities directed toward it" (Martin 2011, p. 8). Accordingly, hope is about desire, pathways and agency (Snyder et al. 1991). Although the concept of hope incorporates aspirations and expectations (Lybbert and Wydick 2018), hope is more active and process-focused than aspirations and expectations and includes the ability to make and carry out plans for the future (Bailey et al. 2007).

More specifically, we examine whether hope mediates the relationship between income increases and SWB using three-wave panel data from a sample from the US population. Our study adds to the existing literature in two distinct ways. First, we contribute to the academic work that has examined how rising income can affect SWB by further investigating the role of psychological changes following increased financial security (Frey and

\footnotetext{
1 This thus is something different from the more widely known 'Broaden and Build Theory' (Fredrickson, 2001), which posits that people who experience positive emotions broaden their thought-action repertoires, making them more resilient. Here, we posit that people perceive their life more positively if they experience positive thoughts and feelings about their future.

2 Also, the importance of the 'sustainability' of income might partly explain the apparent paradox of the relatively limited predictive power of income on happiness (Easterlin 1973; Diener et al. 2013), since income might not add to happiness greatly if it does not bring with it a sense of security and improved future prospects, due to other factors such as a changing economic landscape or job-insecurity.
} 
Stutzer 2002; Diener et al. 2013; Tay et al. 2017). To the best of our knowledge, this is the first study that examines whether hope mediates the relationship between income and SWB. ${ }^{3}$ Second, our research contributes to a myriad of studies, mostly within the field of psychology, on the mediating role of hope between SWB and individual, societal and psychosocial factors, such as personality (Halama 2010), secure attachment (Shorey et al. 2003; Blake et al. 2017), psychological vulnerability (Satici 2016), stress (Ong et al. 2006; Rustøen et al. 2010), meaning in life and purpose (Cotton Bronk et al. 2009; Yalçin and Malkoç, 2015), self-compassion (Yang et al. 2016), and religious and scientific attitudes (Wnuk and Marcinkowski 2014; Aghababaei et al. 2016). Most of this research has focused on subjective circumstances and personality characteristics, and only limitedly on objective circumstances such as income. ${ }^{4}$

\section{Related Literature}

In this study, we look at the link between income and SWB, and investigate whether this relation is mediated by hope, assuming that income adds to SWB at least partly because it helps people feel more hopeful about the future. There are several indications in previous research for both parts of the mediating relation: from income to hope and from hope to SWB.

\subsection{Income and Hope}

With regard to the first relation, between income and hope, previous research elucidates three possible mechanisms through which higher income could increase hope. First, financial security strengthens our inclination to think about and desire positive future events. For example, there is some empirical evidence that an income rise increases aspirations (Easterlin 2001; Stutzer 2004) and expectations (Foster et al. 2012). As such, having a sufficiently high income seems to offer people room to think about and anticipate positive things in the future. Second, a rise in income can increase people's agency and their conviction that they have the ability to pursue their hopes. Various studies have found that higher income is related to increased feelings of autonomy, control, competence and self-efficacy ${ }^{5}$ (Downey and Moen 1987; Ward and King 2019) whereas prolonged poverty has been found to often go hand in hand with depression, anxiety and passivity ${ }^{6}$ (Belle and Doucet 2003; Santiago et al. 2011; Duflo 2012). Thus, it seems that financial security also offers people the confidence that they are able to pursue their hopes. Third, increased income strengthens the capacity to find pathways to materialize our hopes. Previous research for example indicates

\footnotetext{
${ }^{3}$ Our study bears most resemblance to the work of Diener et al. (2013), who found that - next to increasing material possessions and financial satisfaction-optimistic expectations partly mediate the relationship between income and SWB. Apart from focusing on positive expectations instead of hope, the work of Diener et al. (2013) is, however, mostly exploratory in nature and does not contain an elaborate discussion of why this is the case.

4 An exception in this regard is the study of Cheung (2016), which examined how hope mediates the relationship between income inequality and SWB.

5 Self-efficacy here refers to 'people's judgements of their capabilities to organize and execute courses of action required to attain designated types of performances' (Bandura 1986, p. 391).

6 Along these lines, a lack of seeing pathways out of a difficult situation may be associated with enduring poverty, i.e. a 'poverty trap' (Duflo 2012).
} 
that higher income is often accompanied by increased creativity, innovation, resourcefulness and entrepreneurship (Lee et al. 2004; Squalli and Wilson 2014; Tongchaiprasit and Ariyabuddhiphongs 2016). Conversely, in the development studies literature it has been shown that poverty can induce internal constraints to progress, which withhold the poor from engaging in future-oriented behaviours. In a recent study, Lybbert and Wydick (2018) argue that the belief that some form of action will positively affect our future is pivotal for pro-active behaviour. So, there are good reasons to believe that increased income will go together with resourcefulness when it comes to following our hopes.

Although there is no research yet showing that income increases hope specifically, there are overall strong indications that higher income goes together with higher desires, expectations and resourcefulness when it comes to our future.

\subsection{Subjective Well-Being}

The concept of SWB concerns the appreciation of one's life as a whole, and that it comprises affective experiences (e.g., moods, emotions, affectivity) and cognitive comparisons (e.g., life satisfaction, Diener 1984; Diener et al. 1999; Veenhoven 2011). Moreover, SWB can be considered in general and within specific life domains (e.g., relationship satisfaction and job affect). Although all SWB constructs are highly dependent on each other (Diener et al. 1999), the different components can function quite differently. For example, while positive emotions have been found to be correlated to the fulfilment of psychological needs, such as safety and autonomy, the more cognitive evaluation of life satisfaction is much more closely related to economic matters such as income (Veenhoven 2011; Diener et al. 2010). Since we will be focusing on the mechanisms relating SWB to income, we therefore choose to primarily focus on life satisfaction in this study. However, we will also examine whether other components of SWB (i.e. affect and overall happiness) are affected by income and hope in a similar way.

\subsection{Three Different Types of Views of the Future}

In this study, we assume that hope is related to higher SWB. However, previous research on the relation between 'perspectives of the future' and SWB has yielded mixed and sometimes even contradictory findings; while some state that more hope is pretty much always better, others warn for disappointment and disillusionment. This can largely be explained by the difference in concepts used when talking about 'perspectives on the future'; aspiration, expectation or hope.

\subsubsection{Aspirations}

A first strand of research focuses on aspirations, the strong desire or ambition to reach certain goals. It has been posited that higher aspirations decrease SWB because they cause people to be disappointed about their current situation (Easterlin 2001). Moreover, it is assumed that aspirations increase in proportion to income due to adaptation to a certain level of welfare and social comparisons to others, thus meaning that the more we have, the more we want, and the unhappier we become (Van Praag and Kapteyn 1973; Easterlin 1995). This hedonic treadmill would in turn explain why income would be a somewhat limited predictor of SWB, especially the affective component (Kahneman and Deaton 2010). And indeed, some empirical evidence seems to indicate that increased income is 
associated with higher aspirations, dampening at least some of its positive effect on wellbeing (Stutzer 2004; Van Praag and Ferrer-i-Carbonell 2004). Conversely, a lack of resources is found to induce 'aspirations failure'; as people live in prolonged poverty, they start to lose their ambitions, partly because they lose hope and partly because their resources simply run short of being used as a meaningful investment (Dalton et al. 2015; Banerjee et al. 2015). Thus, in general, when focusing on aspiration, research finds that both very low and very high aspirations can be harmful for SWB.

\subsubsection{Expectations}

A second branch of research focuses on expectations; the belief that the future will be positive. Although aspirations and expectations both involve assessments of one's future state, there are also important differences between the two concepts. Aspirations are standards of living that individuals want to achieve and are not dependent on the likelihood of it actually happening. Expectations relate to future states that individuals imagine they are likely to achieve, taking into account their current capabilities, constraints and opportunities (Hanson 1994; Greenaway et al. 2015). It is often assumed that, in order to form expectations, people rationally compute the probabilities of a positive future event happening (Tversky and Kahneman 1979). However, more recent studies indicate that expectations also directly serve a psychological need and offer utility benefit in the form of positive feelings of anticipation (Foster and Frijters 2014). Such (moderate) optimistic expectations are usually found to be related to higher SWB. Previous studies, for example, show that optimistic (financial) expectations predict life satisfaction better than actual income (Frijters et al. 2012; Ekici and Koydemir 2016); that moderately optimistic people can cope better with exogenous shocks (Arampatzi et al. 2020); and that the effect of unemployment on SWB considerably depends on someone's perceived future employability (Green 2011). However, these studies also warn about expectations that are too high, since subjective wellbeing seems to decrease if an outcome is worse than expected due to disappointment (Tversky and Kahneman 1979; Bell 1985; Schwartz 2002; Gollier and Muermann 2010; Sweeny and Shepperd 2006; Arampatzi et al. 2020).

\subsubsection{Hope}

A third and somewhat different strand of research, which takes centre stage in this study, is rooted mainly in the field of psychology. Here, the central focus is on hope. In its most elementary sense, hope can be defined as an endorsed desire for an uncertain but possible event (Martin 2011). Although the concept of hope incorporates aspirations and expectations, in the sense that it is about desire (aspiration) that is possible (expectation) (Lybbert and Wydick 2018), the construct differs from these concepts in two important ways, both related to uncertainty. First, hope is inherently agentic, active. When we expect something to happen, there is no need to do anything about it, since we think it will happen anyway. But when we hope for something, it is uncertain whether we will reach this goal and we will therefore have to take action if possible. Second, hope is process-oriented; while expectations and aspirations mainly relate to the goals we like to achieve, hope also relates to the pathways we come up with to get there and the inherent uncertainty of this process (Snyder 2000). So, the concept of hope thus encompasses both aspirations and expectations, but extends beyond them and therefore offers unique insights into how people perceive the future. 
Hope plays a complex role in our daily lives and society at large, and as such, many different definitional theories have been developed over time, each highlighting (slightly) different dimensions of the concept. Some theories have, for example, underscored its social or (early) attachment components (Erikson 1950; Marcel 2010; Du and King 2013); its emotional traits (Averill Catlin and Chon 1990; Fredrickson 2001); or its relation to goaldirected behaviour (Snyder 1991; Stotland 1969). Other theories aim to offer a comprehensive overview of all traits of hope, and how these traits are generally related (Herth 1991; Webb 2007; Schrank et al. 2010; Krafft et al. 2019). Scioli and colleagues, for example, define hope as a future-oriented emotion network, comprising mastery, attachment, survival and spirituality, constructed from biological, psychological and social resources (Scioli et al. 2011; Magnano et al. 2019). Since hope can manifest itself in many different forms, dependent on the specific context, all these theories seem to have some merit. In this study, we focus on the most widely used hope theory within psychology, developed by Snyder and colleagues, which posits that hope contains three main characteristics: desire; something we want; agency; the conviction that it is possible to attain our hope; and pathways; our creative ability to come up with different pathways or behaviours to attain our hopes even if we face adversity (Snyder et al. 1991).

With regard to the relationship between hope and SWB, there have been several studies that found a positive association (Bailey et al. 2007; Bailey and Snyder 2007; Alarcon, Bowling and Khazon. 2013) or even a direct, causal effect of hope on future SWB (Ciarrochi et al. 2015). This relation is often explained with regard to behaviour as well as perception. On the one hand, people who have higher hopes are supposedly more inclined to invest in their future and therefore exhibit constructive behaviours that will lead to more favourable outcomes (for example studying for exams or working for a promotion). On the other hand, these hopeful people will also immediately incorporate their positive view into their SWB evaluation; i.e. they simply enjoy feeling hopeful. Along these lines, an income increase does not only increase SWB by increasing current consumption, but also through the savouring of positive feelings of anticipation of future standards of living (Loewenstein 1987).

All in all, there are good reasons to assume that hope, similar to expectations and aspirations, follows from increased income. Moreover, a (moderately) hopeful disposition is most likely related to higher SWB. However, contrary to the research fields on aspirations and expectations, little is known about the possible disappointment that may follow from being extremely hopeful. Because hope is active and process-oriented, it can be argued that, contrary to expectations and aspirations, hope is less prone to disillusionment. However, if this isn't the case, it is important to know that more hope isn't always better. In this study, we will therefore first analyse whether hope mediates the relation between income and SWB, and then compare hope to often used measures of expectation in relation to SWB, to see whether they exhibit a non-linear relation, suggesting a 'disappointment effect'.

\section{Data and Methods}

\subsection{Participants}

Three-wave panel data was collected in the US in 2016, 2017 and 2018 using Prolific. Similar to Amazon's Mechanical Turk, Prolific is a virtual crowdsourcing platform where people can complete tasks for a small compensation. Specifically aimed at collecting high 
Table 1 Demographics

\begin{tabular}{|c|c|c|c|c|}
\hline & Year 1 & Year 2 & Year 3 & US census \\
\hline Number of participants & 511 & 340 & 205 & $327.2 \mathrm{mln}$ \\
\hline Age & 33 & 34 & 38 & 38 \\
\hline \multicolumn{5}{|l|}{ Gender } \\
\hline Male & $58 \%$ & $56 \%$ & $56 \%$ & $49 \%$ \\
\hline Female & $42 \%$ & $44 \%$ & $44 \%$ & $51 \%$ \\
\hline \multicolumn{5}{|l|}{ Household composition } \\
\hline Single & $44 \%$ & $39 \%$ & $36 \%$ & $28 \%$ \\
\hline Single parent & $5 \%$ & $6 \%$ & $4 \%$ & $9 \%$ \\
\hline Couple without children & $22 \%$ & $27 \%$ & $26 \%$ & $29 \%$ \\
\hline Couple with children & $23 \%$ & $21 \%$ & $27 \%$ & $19 \%$ \\
\hline Other & $6 \%$ & $7 \%$ & $6 \%$ & $15 \%$ \\
\hline \multicolumn{5}{|l|}{ Ethnicity } \\
\hline White & $74 \%$ & $79 \%$ & $83 \%$ & $73 \%$ \\
\hline Black/African American & $10 \%$ & $11 \%$ & $8 \%$ & $13 \%$ \\
\hline Asian & $3 \%$ & $6 \%$ & $5 \%$ & $5 \%$ \\
\hline Other & $10 \%$ & $5 \%$ & $5 \%$ & $9 \%$ \\
\hline \multicolumn{5}{|l|}{ Religion } \\
\hline Very important & $10 \%$ & $12 \%$ & $12 \%$ & $53 \%$ \\
\hline Important & $14 \%$ & $14 \%$ & $16 \%$ & $24 \%$ \\
\hline Slightly important & $20 \%$ & $15 \%$ & $15 \%$ & $11 \%$ \\
\hline Not at all important & $56 \%$ & $59 \%$ & $55 \%$ & $11 \%$ \\
\hline
\end{tabular}

quality responses for scientific research, Prolific monitors participants closely with several checks to make sure only trustworthy responses are collected. The platform has been used in many empirical studies in the social sciences (Sheehan 2017), and data provided by Prolific respondents has proven to be of good quality (Peer et al. 2017). Overall, 515 respondents completed the first wave of this study. Of these respondents, 341 also completed all relevant questions in the second wave and 199 in the third. A comparison with US census information, which can be found in Table 1, shows that the sample is relatively well representative of the population, although single-households, males, young people and Asians are somewhat over-represented in the sample, while African Americans are somewhat underrepresented (U.S. Census Bureau 2017; The Demographic Statistical Atlas, n.d.). The sample does differ significantly from the US population on religiosity; the respondents score religion as much less important. Although the sample is thus representative of the US population on some important demographic characteristics, it is not representative on all traits.

Along with personal characteristics, in each of the three waves respondents reported their life satisfaction, overall happiness, experience of positive and negative emotions (affect), hope, expectations for the next year with regard to their standard of living, and monthly income (see Table 2). It is difficult to assess to what degree the values on some of these main variables compare to those found in the U.S. population, since we have no census information on, for example, SWB, hope or expectations. On a whole, however, this sample appears to experience somewhat fewer positive states, which could be linked to the lower level of religiosity of respondents, a personal trait usually linked to positive 
Table 2 Variables of interest

\begin{tabular}{llll}
\hline & Year 1 & Year 2 & Year 3 \\
\hline Life satisfaction (0-10) & 6.30 & 6.28 & 6.16 \\
Happiness (0-10) & 6.37 & 6.38 & 6.26 \\
Affect (0-10) & 5.84 & 5.98 & 6.17 \\
Hope (1-7) & 4.84 & 4.94 & 5.12 \\
Agency & 4.68 & 4.82 & 4.97 \\
Pathways & 5.00 & 5.05 & 5.27 \\
Expectations living standards & & & \\
Better & $37 \%$ & $33 \%$ & $27 \%$ \\
The same & $50 \%$ & $53 \%$ & $48 \%$ \\
Worse & $13 \%$ & $15 \%$ & $24 \%$ \\
Monthly income & & & \\
Less than $\$ 900$ & $6 \%$ & $6 \%$ & $6 \%$ \\
\$900-\$1300 & $10 \%$ & $11 \%$ & $8 \%$ \\
\$1300-\$1800 & $13 \%$ & $10 \%$ & $8 \%$ \\
\$1800-\$2700 & $26 \%$ & $16 \%$ & $15 \%$ \\
\$2700-\$3200 & $16 \%$ & $15 \%$ & $13 \%$ \\
More than \$3200 & $29 \%$ & $42 \%$ & $51 \%$ \\
\hline
\end{tabular}

experiences in the U.S. (2010). The mean score of 6.25 for life satisfaction is somewhat lower than the mean score of 6.89 that the U.S. scores in the World Happiness Report (Helliwell Layard and Sachs 2019). Moreover, the respondents in this sample appear to be more cautious in their expectations compared to those studied in the Gallup U.S. Daily survey; while a relatively comparable group of around $20 \%$ of the Gallup survey think their standard of living will get worse, around $60 \%$ percent expects an improvement, almost twice the number in our sample (Norman 2017). Although somewhat on the low side, the mean hope scores fall well within the range of expected scores (Lopez et al. 2000). Lastly, the scores on income are quite low compared to the population, with over half scoring below the U.S. median income of $\$ 4900$ (U.S. Census Bureau 2017). It is important to note, however, that respondents were asked for base income, excluding any bonuses, holiday pay or benefits, which somewhat increases the plausibility of these results. Moreover, although respondents could also pick income categories over $\$ 3200$ a month, these higher income categories weren't asked consistently over the years, meaning that we had to merge them, and can only analyse the data for the income distribution up to $\$ 3200$. $^{7}$

The Cronbach's alpha for the full hope scale was $0.88,0.91$ and 0.93 for year 1,2 and 3; while the agency subscale yielded a $0.84,0.87$ and 0.88 ; and the pathways subscale a 0.79 , 0.85 and 0.88 . Hence, all scales appear to have acceptable, and with the exception of the pathways subscale in year 1 , even good internal consistency.

To examine whether people who participated in all years are significantly different from those who dropped out at one point, we performed a t-test on hope and life satisfaction for these groups and calculated a $\mathrm{chi}^{2}$ for the relation between retention, i.e. the chance to keep participating and income. Respondents who participated all years scored a 6.18

\footnotetext{
7 Sensitivity analyses using only the two waves with consistent income categories up to $\$ 5,000$ a month however indicate that our findings also apply to higher income categories.
} 
$(\mathrm{SD}=0.17)$ on life satisfaction and $4.91(\mathrm{SD}=0.08)$ on hope, whereas respondents who participated multiple years scored a $6.39(\mathrm{SD}=0.12)$ and $4.80(\mathrm{SD}=0.06)$ respectively. The difference between the groups of respondents is not significant both when it comes to life satisfaction $(\mathrm{t}=1.05, \mathrm{p}=0.29$, two-tailed) and hope $(\mathrm{t}=-1.25, \mathrm{p}=0.21$, two-tailed). Moreover, differences in the levels of income between the two groups are not significant either $\left(\mathrm{chi}^{2}(5)=6.09, \mathrm{p}=0.30\right)^{8}{ }^{8}$

Similarly, we checked whether the groups differ in terms of any other personal characteristics. We do not find a significant relation of retention with gender $\left(\mathrm{chi}^{2}(1)=1.27\right.$ $\mathrm{p}=0.26)$, household composition $\left(\mathrm{chi}^{2}(4)=0.90 \mathrm{p}=0.92\right)$, religiosity $\left(\mathrm{chi}^{2}(3)=4.82\right.$ $\mathrm{p}=0.19)$ or ethnicity $\left(\mathrm{chi}^{2}(3)=3.82 \mathrm{p}=0.28\right)$. However, there is a relation with age $(30.2$ versus 36.2 years, $\mathrm{t}=-6.03, p<0.01$, two-tailed) that is, younger people are more likely to drop out of the sample.

\subsection{Materials}

\subsubsection{Demographics}

Respondents reported their age, gender, household composition, religiosity and ethnicity. These characteristics were included as covariates. Demographics for the sample can be found in Table 1.

\subsubsection{Subjective Well-Being}

In the main analyses in this study, we focus on life satisfaction, using a single item life satisfaction question, which asked respondents how satisfied they are with their life as a whole, ranging from 0 (very dissatisfied) to 10 (very satisfied) (Cheung and Lucas 2014). Please note that although psychological studies frequently use the Satisfaction with Life Scale (Diener et al. 1985), several studies have by now found that single-item happiness measures have acceptable validity (Cheung and Lucas 2014; Schimmack and Oishi 2005). Respondents reported a 6.3 in year 1 and 2, and a 6.2 in year 3 for average life satisfaction, which is lower than the American average of 6.9 (Veenhoven, 2018). In addition, the survey included two measures that addressed the more emotional components of SWB. First, we included a measure for overall happiness, also measured with a single item, asking respondents when taking all things together to assess how happy they are (2006). Scores ranged from 0 (very unhappy) to 10 (very happy), the average score was a 6.4 in the first and second wave and 6.3 in the third wave. Finally, the affective component of subjective well-being was assessed using the short version of the Positive and Negative Affect Schedule (PANAS; see Watson et al. 1988). This scale represents the balance of positive and negative emotions that participants experienced in the past month and scores range from 1 (only negative emotions) to 7 (only positive emotions). For the first, second and third wave, respondents scored a 5.8, 6.0 and 6.2 respectively.

$\overline{{ }^{8} \text { A comparison between the different years can be found in "Appendix B". }}$ 


\subsubsection{Hope}

Hope was measured using the Adult Trait Hope Scale by Snyder et al. (1991). The scale contains 12 items (of which 4 are used as distracters), where participants have to rate statements such as 'I can think of many ways to get out of a jam' and 'My past experiences have prepared me well for my future'. Possible answers ranged from 1 (Definitely false) to 7 (Definitely true) and the scale can be subdivided into two subscales: one for agency (indicating someone believes she or he is capable of achieving their hopes) and one for pathways (meaning someone can come up with several pathways towards hoped for goals). Individuals that score high on the Snyder scale are regarded as more hopeful, more motivated to achieve their goals, and better able to think of ways to reach their goals. Previous research has found this scale to be valid in measuring hope and its two subscales agency and pathways (Alarcon et al. 2013). A full list of the items of the Adult Trait Hope Scale, including how these items fall into the two subscales can be found in "Appendix A".

\subsubsection{Economic Expectations}

Economic expectations were measured using a single-item question asking whether respondents expected their living standards to get better, stay the same or get worse over the next year.

\subsubsection{Income}

Respondents were asked to report their net household income in categories, ranging from less than $\$ 900$, between $\$ 900$ and $\$ 1300, \$ 1300$ to $\$ 1800, \$ 1800$ to $\$ 2700, \$ 2700$ to $\$ 3200$, and more than $\$ 3200$.

\subsection{Analysis}

Using a fixed effects regression model, the relation between change in income, hope and life satisfaction is estimated. This type of model uses the variation within respondent's scores to calculate the relation between variables, meaning that time-invariant personal characteristics, such as personality, are controlled for. We use the following model:

$$
S W B_{i t}=\beta_{0}+\text { Income } * x_{i t}+\text { Hope } * x_{i t}+C V_{i t}+\alpha_{i}+u_{i t}
$$

where i denotes a person at time t, SWB refers to the different dimensions of Subjective Well-Being (i.e. life satisfaction, happiness or affect), Hope represents the hope-score of the respondent, $\mathrm{CV}$ represents a set of control variables, $\alpha_{i}$ captures all unobserved, timeconstant factors that affect $S W B_{i t}$, and $u_{i t}$ represents factors affecting $S W B_{i t}$ that change over time. To investigate whether hope mediates the relation between income and SWB, several models are used. First, we investigate the relation between income and SWB in a model without hope; then, hope is included and we check whether the difference in regression coefficients is significant. Lastly, we replace SWB with hope as the dependent variable, and check whether income predicts hope. To further investigate the mediation effect, a bootstrapped mediation test for categorical independent variables is used. Lastly, to see whether there is linear or curvilinear relation of SWB with hope and expectations, a squared term is included in a fixed effects regression of SWB on hope and expectation. 
Table 3 Changes over the years in variables of interest

\begin{tabular}{lll}
\hline & Year 1-year 2 & Year 2-year 3 \\
\hline Life satisfaction (0-10) & & \\
4 points or more down & $3 \%$ & $4 \%$ \\
1-3.9 points down & $35 \%$ & $32 \%$ \\
No change & $26 \%$ & $28 \%$ \\
1-3.9 points up & $32 \%$ & $32 \%$ \\
4 points or more up & $4 \%$ & $3 \%$ \\
Income (1-6) & & \\
3 categories or more down & $7 \%$ & $8 \%$ \\
1-2 categories down & $12 \%$ & $11 \%$ \\
No change & $44 \%$ & $57 \%$ \\
1-2 categories up & $26 \%$ & $15 \%$ \\
3 or more categories up & $12 \%$ & $9 \%$ \\
Hope (1-7) & & \\
1.5 points or more down & $4 \%$ & $3 \%$ \\
$0.5-1.4$ points down & $21 \%$ & $17 \%$ \\
Less than 0.5 change & $48 \%$ & $48 \%$ \\
$0.5-1.4$ points up & $22 \%$ & $27 \%$ \\
1.5 points or more up & $4 \%$ & \\
\hline
\end{tabular}

The categories in this table are created with the aim to represent the distribution of respondents who experienced no change; versus a small; or larger change. Please note that this categorization is solely used to describe the sample and is not used in further analyses

\section{Results}

Since the fixed effects model we use, analyzes the relation between changes in life satisfaction, income and hope, we first examine whether the respondents actually experienced changes in these variables over the years. As can be seen in Table 3, there is quite some variability when it comes to life satisfaction; about a third of the sample experiences more than 1-point change compared to the previous year. Income and hope are more stable; about half of the sample experiences no change in these variables over the years. However, since also about half of the sample does experience a change, we assume to have enough variability in the variables of interest to perform a fixed effects analysis.

\subsection{Hope as a Mediator}

The results from the baseline model (1) presented in Table 4 show that there is a moderately strong and positive relationship between income and life satisfaction. Compared to a monthly income of less than $\$ 900$, all higher income categories are significantly related to a higher level of life satisfaction. The effect sizes range from 0.7 points (on a 0 to 10 scale) for people earning between $\$ 900$ and $\$ 1300$ and 1.2 points for people earning over $\$ 3200$ a month. When hope is included in the model (model 2), the effects remain significant, but the effect sizes are reduced slightly, now ranging between 0.6 (for $\$ 900$ to $\$ 1299$ ) and 0.8 (for those earning more than \$3200). When comparing the two models, only the difference for the higher income categories, i.e. $\$ 1800$ or higher, are significant (column 
Table 4 Fixed effects regression model on life satisfaction and hope

\begin{tabular}{llllll}
\hline & $(1)$ & $(2)$ & $(1-2)$ & $(3)$ & $(4)$ \\
& LS & LS & Difference & LS & Hope \\
\hline Income & & & & & \\
$<\$ 900$ & Reference & Reference & & & Reference \\
$\$ 900-\$ 1299$ & $0.739^{\mathrm{b}}$ & $0.609^{\mathrm{b}}$ & 0.130 & & 0.115 \\
& $(0.335)$ & $(0.302)$ & & $0.144)$ \\
$\$ 1300-\$ 1799$ & $0.793^{\mathrm{b}}$ & $0.673^{\mathrm{b}}$ & 0.120 & & 0.139 \\
& $(0.327)$ & $(0.293)$ & & & $(0.140)$ \\
$\$ 1800-\$ 2699$ & $0.924^{\mathrm{c}}$ & $0.628^{\mathrm{b}}$ & $0.296^{\mathrm{a}}$ & & $0.245^{\mathrm{a}}$ \\
& $(0.335)$ & $(0.302)$ & & & $(0.143)$ \\
$\$ 2700-\$ 3199$ & $0.997^{\mathrm{c}}$ & $0.704^{\mathrm{b}}$ & $0.293^{\mathrm{a}}$ & & $0.273^{\mathrm{a}}$ \\
& $(0.341)$ & $(0.307)$ & & & $(0.146)$ \\
More than $\$ 3200$ & $1.194^{\mathrm{c}}$ & $0.750^{\mathrm{b}}$ & $0.440^{\mathrm{c}}$ & & $0.408^{\mathrm{c}}$ \\
& $(0.350)$ & $(0.319)$ & & & $(0.151)$ \\
Hope & & $1.126^{\mathrm{c}}$ & & $1.159^{\mathrm{c}}$ & \\
& & $(0.100)$ & & $(0.090)$ & \\
Constant & $8.874^{\mathrm{c}}$ & 2.870 & & 3.208 & $5.047^{\mathrm{c}}$ \\
& $(2.694)$ & $(2.475)$ & & $(2.256)$ & $(1.153)$ \\
$\mathrm{R}^{2}$ (within) & 0.077 & 0.283 & & 0.298 & 0.072 \\
$N$ (groups) & 327 & 327 & & 339 & 327 \\
\hline
\end{tabular}

Robust standard errors in parenthesis

All models are corrected for age, age squared, gender, household composition, religiosity and year-dummies

${ }^{\text {a }}$ Significant at the 0.1 level

${ }^{\mathrm{b}}$ Significant the 0.05 level

${ }^{\mathrm{c}}$ Significant at the 0.01 level

3, difference between model 1 and 2) and only with $90 \%$ certainty for incomes between $\$ 1800$ and 3199, indicating that correcting for hope significantly alters the relation between income and life satisfaction, but only for people with a higher income. Moreover, we find that the relation between hope and life satisfaction is moderately strong and positive and hardly changes between the models with or without income (model 2 and 3). On average, a one-point increase in hope (on a scale of 1 to 7), generally leads to a 1.2-point increase in life satisfaction (on a scale of 0 to 10), signalling a strong positive relation. Also, the predictive value of the overall model more than doubled by incorporating hope. Lastly, we test whether a higher income is related to higher hopes, which is the case for incomes over $\$ 1800$, with effect sizes ranging from 0.2 to 0.4 points on a 7-point scale for people earning between $\$ 1800$ and $\$ 2699$, and over $\$ 3200$ respectively. The relation between hope and income is not significant for people with an income lower than $\$ 1800$.

To sum up, for incomes over $\$ 1,800$ our hypothesized independent variable, income, is related to our mediator, hope, which is in turn related to our dependent variable, life satisfaction; and including our mediator significantly reduces the relation between the independent and dependent variable for higher income; thus meeting the criteria for mediation for this subgroup of people.

To further study the size of the mediating effect of hope, we calculate the total indirect effect of income on life satisfaction through hope $(1.30, p<0.01 \mathrm{SE}=0.49)$; and the total 
Table 5 Fixed effects regression model on life satisfaction and hope

\begin{tabular}{|c|c|c|c|c|c|c|}
\hline & \multicolumn{3}{|l|}{ Agency } & \multicolumn{3}{|l|}{ Pathways } \\
\hline & $\begin{array}{l}(1) \\
\mathrm{LS}\end{array}$ & $\begin{array}{l}\text { (T4.1-1) } \\
\text { Difference }\end{array}$ & $\begin{array}{l}(2) \\
\text { Hope-agency }\end{array}$ & $\begin{array}{l}(3) \\
\mathrm{LS}\end{array}$ & $\begin{array}{l}(\mathrm{T} 4.1-3) \\
\text { Difference }\end{array}$ & $\begin{array}{l}\text { (4) } \\
\text { Hope-pathways }\end{array}$ \\
\hline \multicolumn{7}{|l|}{ Income } \\
\hline$<\$ 900$ & Reference & & Reference & Reference & & Reference \\
\hline$\$ 900-\$ 1300$ & $\begin{array}{l}0.597^{\mathrm{b}} \\
(0.294)\end{array}$ & 0.142 & $\begin{array}{l}0.132 \\
(0.134)\end{array}$ & $\begin{array}{l}0.671^{\mathrm{b}} \\
(0.325)\end{array}$ & 0.068 & $\begin{array}{l}0.099 \\
(0.161)\end{array}$ \\
\hline$\$ 1300-\$ 1800$ & $\begin{array}{l}0.658^{\mathrm{b}} \\
(0.285)\end{array}$ & 0.135 & $\begin{array}{l}0.137 \\
(0.159)\end{array}$ & $\begin{array}{l}0.738^{\mathrm{b}} \\
(0.315)\end{array}$ & 0.055 & $\begin{array}{l}0.098 \\
(0.156)\end{array}$ \\
\hline$\$ 1800-\$ 2700$ & $\begin{array}{l}0.624^{\mathrm{b}} \\
(0.294)\end{array}$ & $0.300^{\mathrm{a}}$ & $\begin{array}{l}0.260 \\
(0.163)\end{array}$ & $\begin{array}{l}0.746^{\mathrm{b}} \\
(0.324)\end{array}$ & $0.178 *$ & $\begin{array}{l}0.230 \\
(0.160)\end{array}$ \\
\hline$\$ 2700-\$ 3200$ & $\begin{array}{l}0.631^{\mathrm{b}} \\
(0.299)\end{array}$ & $0.366^{\mathrm{b}}$ & $\begin{array}{l}0.354^{\mathrm{b}} \\
(0.166)\end{array}$ & $\begin{array}{l}0.880^{c} \\
(0.329)\end{array}$ & 0.117 & $\begin{array}{l}0.192 \\
(0.163)\end{array}$ \\
\hline More than $\$ 3200$ & $\begin{array}{l}0.707^{\mathrm{b}} \\
(0.310)\end{array}$ & $0.487^{\mathrm{c}}$ & $\begin{array}{l}0.467^{\mathrm{c}} \\
(0.171)\end{array}$ & $\begin{array}{l}0.971^{\mathrm{c}} \\
(0.342)\end{array}$ & $0.223^{\mathrm{b}}$ & $\begin{array}{l}0.349^{\mathrm{b}} \\
(0.169)\end{array}$ \\
\hline Hope-agency & $\begin{array}{l}1.075^{\mathrm{c}} \\
(0.085)\end{array}$ & & & & & \\
\hline Hope-pathways & & & & $\begin{array}{l}0.683^{c} \\
(0.096)\end{array}$ & & \\
\hline Constant & $\begin{array}{l}3.341 \\
(2.394)\end{array}$ & & $\begin{array}{l}4.845^{\mathrm{c}} \\
(1.313)\end{array}$ & $\begin{array}{l}4.969^{\mathrm{a}} \\
(2.652)\end{array}$ & & $\begin{array}{l}5.248^{c} \\
(1.291)\end{array}$ \\
\hline $\mathrm{R}^{2}$ (within) & 0.321 & & 0.063 & 0.310 & & 0.050 \\
\hline$N$ (groups) & 327 & & 327 & 327 & & 327 \\
\hline
\end{tabular}

Robust standard errors in parenthesis

All models are corrected for age, age squared, gender, household composition, religiosity and year-dummies ${ }^{\text {a }}$ Significant at the 0.1 level

${ }^{\mathrm{b}}$ Significant the 0.05 level

${ }^{\mathrm{c}}$ Significant at the 0.01 level

direct effect, i.e. the relation between income and life satisfaction that is not affected by controlling for hope $(3.36, p=<0.01, \mathrm{SE}=0.90)$. These analyses indicate that there is both a significant and positive indirect effect from income via hope and a significant positive direct effect, indicating that hope only partially mediates the relation between income and life satisfaction. About $28 \%$ of the relation between income and life satisfaction appears to be mediated by hope. More specifically, it indicates that there is a significant mediating effect for the income categories over $\$ 1800$, but not for those with lower incomes.

\subsection{Components of Hope}

Hope as measured in this study is a two-dimensional concept, comprising agency, i.e. a sense that someone is capable of reaching important goals, and pathways, i.e. being inventive in coming up with different routes towards a desired goal. To test whether these dimensions are equally important in mediating the relation between income and life satisfaction, 
we run the same analysis as before for each dimension. The results are reported in Table 5. Here we can see that the agency component seems to reduce the relation between income and life satisfaction more strongly (column 2 and 5, representing the difference between the uncorrected model 1 in Table 4 and the corrected models 1 and 3 in Table 5) and that this component is more strongly related to life satisfaction (regression-coefficient 1.1 for agency versus 0.7 for pathways), indicating that agency is responsible for a larger portion of the mediation.

Altogether, the overall mediating effect is stronger for agency; about $27 \%$ of the total effect is mediated by this component (total indirect effect $=1.28, p=0.02, \mathrm{SE}=0.54$ ) while this only is about $14 \%$ for pathways (total indirect effect $=0.66, p<0.05, \mathrm{SE}=0.33$ ). So, we can conclude that the agency component is a stronger mediator for the relation between income and life satisfaction.

Previous studies have also found that agency is more strongly related to life satisfaction, indicating that to be content with our lives, it is especially important to feel motivated and able to achieve ones goals (Bailey et al. 2007; Pleeging, Burger and van Exel 2019). Also, agency appears to be the stronger mediator between a sense of purpose in life and life satisfaction, implying that the feeling that we are able to progress towards meaningful 'ultimate aims' specifically makes us feel satisfied with life (Cotton Bronk et al. 2009). A similar process may apply to income; having more money might make us more satisfied, insofar as it gives us the idea that we can achieve more of what we want. Pathways, i.e. coming up with different ways to get to our goals, on the other hand, might be a more complex, secondary experience, which might play an important role in actual goal-achievement, but less so in our perception of and satisfaction with life (Cotton Bronk et al. 2009).

\subsection{Components of SWB}

As discussed before in paragraph 2.1, SWB comprises both cognitive evaluations and affective experiences. To investigate whether the mediating effect of hope arises for different dimensions of SWB, the analyses are also performed using overall happiness and affect.

\subsubsection{Overall Happiness}

Firstly, as can be seen in Table 6, the relation between income and overall happiness is moderately strong and positive, similar to life satisfaction. Moreover, including hope in the model has a comparable effect: the regression coefficients of income predicting happiness are reduced considerably, but again only for people with an income over $\$ 1,800$.

An analysis of direct $(2.33, p=0.02, \mathrm{SE}=0.96)$ and indirect effects $(1.15, p=0.02$, $\mathrm{SE}=0.48$ ) shows that about $33 \%$ of the total relation between income and happiness is mediated by hope, indicating that the relation between income and happiness is mediated by hope in a similar fashion to life satisfaction. This finding is perhaps not surprising, given that, although overall happiness theoretically refers to a wider concept than life satisfaction, in practice both measures generally yield similar results (OECD 2013).

\subsubsection{Affect}

When we regress income on affect, i.e. the emotional component of SWB, we find virtually no significant relation, with the exception of a small relation (regression coefficient 0.3 
Table 6 Fixed effects regression model on overall happiness and hope

\begin{tabular}{|c|c|c|c|c|}
\hline & $\begin{array}{l}\text { (1) } \\
\text { Happiness }\end{array}$ & $\begin{array}{l}(2) \\
\text { Happiness }\end{array}$ & $\begin{array}{l}(1-2) \\
\text { Difference }\end{array}$ & $\begin{array}{l}(3) \\
\text { Happiness }\end{array}$ \\
\hline \multicolumn{5}{|l|}{ Income } \\
\hline$<\$ 900$ & Reference & Reference & & \\
\hline$\$ 900-\$ 1300$ & $\begin{array}{l}0.648^{a} \\
(0.351)\end{array}$ & $\begin{array}{l}0.512 \\
(0.321)\end{array}$ & 0.136 & \\
\hline$\$ 1300-\$ 1800$ & $\begin{array}{l}0.693^{b} \\
(0.342)\end{array}$ & $\begin{array}{l}0.523 * \\
(0.312)\end{array}$ & 0.170 & \\
\hline$\$ 1800-\$ 2700$ & $\begin{array}{l}0.751^{b} \\
(0.351)\end{array}$ & $\begin{array}{l}0.446 \\
(0.321)\end{array}$ & $0.305^{\mathrm{b}}$ & \\
\hline$\$ 2700-\$ 3200$ & $\begin{array}{l}0.795^{\mathrm{b}} \\
(0.357)\end{array}$ & $\begin{array}{l}0.486 \\
(0.327)\end{array}$ & $0.309^{\mathrm{b}}$ & \\
\hline More than $\$ 3200$ & $\begin{array}{l}0.892^{\mathrm{b}} \\
(0.366)\end{array}$ & $\begin{array}{l}0.424 \\
(0.339)\end{array}$ & $0.468^{c}$ & \\
\hline Hope & & $\begin{array}{l}1.096^{\mathrm{c}} \\
(0.106)\end{array}$ & & $\begin{array}{l}1.121^{\mathrm{c}} \\
(0.097)\end{array}$ \\
\hline Constant & $\begin{array}{l}6.059 \\
(2.821)\end{array}$ & $\begin{array}{l}0.190 \\
(2.631)\end{array}$ & & $\begin{array}{l}2.296 \\
(0.2448)\end{array}$ \\
\hline $\mathrm{R}^{2}$ (within) & 0.069 & 0.428 & & 0.437 \\
\hline$N$ (groups) & 327 & 327 & & 327 \\
\hline
\end{tabular}

Robust standard errors in parenthesis

All models are corrected for age, age squared, gender, household composition and year-dummies

${ }^{\text {a }}$ Significant at the 0.1 level

${ }^{\mathrm{b}}$ Significant the 0.05 level

${ }^{\mathrm{c}}$ Significant at the 0.01 level

with $90 \%$ certainty) for the highest income category. This corroborates previous findings that income is more closely related to the cognitive rather than the emotional component of SWB (Kahneman and Deaton 2010; Diener et al. 2010). Considering that life satisfaction and overall happiness both encompass an evaluation of life compared to some ideal, whereas affect mainly relates to specific emotions and experiences (Luhmann et al. 2012), this finding is perhaps not surprising. Income most likely affects how we perceive our global life circumstances as it is something that we often consider when judging how our overall life is going, while its impact on what we experience on a daily basis may be more limited, especially if we take hedonic adaptation into account, i.e. the human tendency to easily get used to new situations and standards of living (Yu and Chen 2016). Moreover, income can be assumed to increase life's comforts and to help us fulfil our desires, but may be less efficient in fulfilling our fundamental psychological needs such as connectedness, autonomy and competence, whereas the latter has been found to be more closely related to emotional wellbeing (Scitovsky 1978; Diener et al. 2010). Lastly, although higher income has been found to help avoid negative emotions following from deprivation, it appears that it does not necessarily increase positive emotion (Kushlev et al. 2015), however, in this sample neither positive nor negative affect appear to be affected by income. So, although income is generally found to have some positive impact on emotional wellbeing, the relation is generally small, which could explain why in this study, with a relatively small 
Table 7 Fixed effects regression model on life satisfaction and expectations for living standards

\begin{tabular}{|c|c|c|c|c|}
\hline & $\begin{array}{l}\text { (1) } \\
\text { LS }\end{array}$ & $\begin{array}{l}\text { Difference } \\
\text { (T4.1-1) }\end{array}$ & $\begin{array}{l}(3) \\
\mathrm{LS}\end{array}$ & $\begin{array}{l}\text { (4) } \\
\text { Expectations }\end{array}$ \\
\hline \multicolumn{5}{|l|}{ Income } \\
\hline$<\$ 900$ & Reference & & & Reference \\
\hline$\$ 900-\$ 1300$ & $\begin{array}{l}0.340 \\
(0.334)\end{array}$ & $0.399^{\mathrm{b}}$ & & $\begin{array}{l}0.756^{\mathrm{a}} \\
(0.423)\end{array}$ \\
\hline$\$ 1300-\$ 1800$ & $\begin{array}{l}0.395 \\
(0.323)\end{array}$ & $0.398^{b}$ & & $\begin{array}{l}0.886^{\mathrm{b}} \\
(0.408)\end{array}$ \\
\hline$\$ 1800-\$ 2700$ & $\begin{array}{l}0.628^{\mathrm{a}} \\
(0.328)\end{array}$ & $0.296^{\mathrm{b}}$ & & $\begin{array}{l}1.045^{\mathrm{c}} \\
(0.386)\end{array}$ \\
\hline$\$ 2700-\$ 3200$ & $\begin{array}{l}0.743^{b} \\
(0.335)\end{array}$ & $0.254^{\mathrm{a}}$ & & $\begin{array}{l}0.960^{\mathrm{b}} \\
(0.401)\end{array}$ \\
\hline More than $\$ 3200$ & $\begin{array}{l}0.828^{\mathrm{b}} \\
(0.345)\end{array}$ & $0.366^{\mathrm{b}}$ & & $\begin{array}{l}2.079^{c} \\
(0.391)\end{array}$ \\
\hline \multicolumn{5}{|l|}{ Expectations } \\
\hline Getting better & Reference & & Reference & \\
\hline Staying the same & $\begin{array}{l}-0.425^{\mathrm{c}} \\
(0.155)\end{array}$ & & $\begin{array}{l}-0.427^{\mathrm{c}} \\
(0.147)\end{array}$ & \\
\hline Getting worse & $\begin{array}{l}-1.088^{c} \\
(0.222)\end{array}$ & & $\begin{array}{l}-1.189^{c} \\
(0.213)\end{array}$ & \\
\hline Constant & $\begin{array}{l}8.738^{c} \\
(2.649)\end{array}$ & & $\begin{array}{l}10.025^{\mathrm{c}} \\
(2.560)\end{array}$ & \\
\hline $\mathrm{R}^{2}$ (within) & 0.189 & & 0.167 & \\
\hline$N$ (groups) & 327 & & 339 & 327 \\
\hline
\end{tabular}

These results are based on an order logistic regression for panel data, meaning that only the direction and significance of the relation can be incurred, while the strength of the relation cannot be derived from the regression coefficients in this analysis

Robust standard errors in parenthesis

All models are corrected for age, age squared, household composition, religiosity and year-dummies

${ }^{\text {a }}$ Significant at the 0.1 level

${ }^{\mathrm{b}}$ Significant the 0.05 level

${ }^{\mathrm{c}}$ Significant at the 0.01 level

timeframe and sample size, we do not find a significant relation. Although a mediation analysis is still possible with a non-significant main effect, it becomes redundant to our research question aimed at explaining the relation between income and SWB, so no further analyses are included (see "Appendix C" for the full results).

\subsection{Expectations as a Mediator}

In many large-scale studies, economic expectations are used as a measure of optimism or hope. However, it has never been investigated whether expectations are similar to hope in their relation to income and SWB. Here, we therefore test whether an often-used single item measure of economic expectations, i.e. a single item question on expectations 

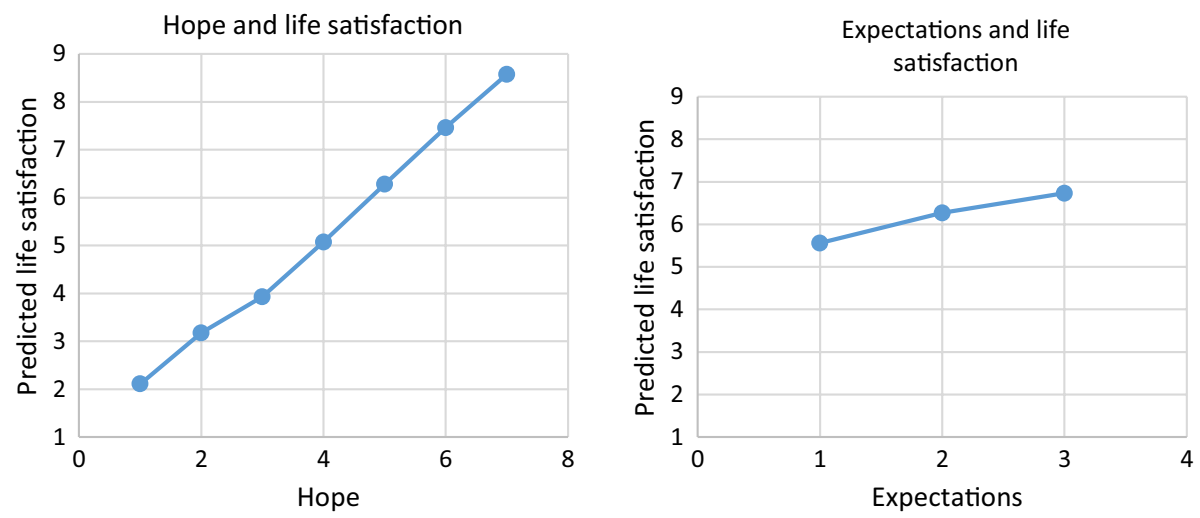

Fig. 1 Predicted life satisfaction based on expectations and hope

regarding the participant's standard of living for the following year, indeed plays the same mediating role as hope.

As can be seen in Table 7, including expectations regarding future living standards does significantly reduce the relation between income and life satisfaction. The difference between the uncorrected (Table 4, model 1) and the corrected model (Table 7, model 1) is quite similar to that of hope, but while hope seemed to only mediate the relation between life satisfaction and income over $\$ 1800$, this is not the case for expectations; more positive expectations go together with higher income throughout the distribution. Moreover, there is a positive and significant relation between income and expectations. The total indirect effect $(0.538 p=0.03 \mathrm{SE}=0.242)$ indicates that about $14 \%$ of the total relation between income and life satisfaction is mediated by expectations. These findings corroborate the growing number of studies which find that positive expectations matter significantly for our wellbeing, even when controlling for objective life-circumstances (Frijters et al. 2012; Ekici and Koydemir 2016; O’Connor and Graham 2019).

\subsection{The Question of Diminishing Returns on Hope and Life Satisfaction}

Previous studies have hypothesized that (financial) expectations increase SWB only up to a certain point, after which overly optimistic expectations are deemed to become 'false hopes' that actually decrease SWB due to disappointment (Bell 1985; Schwartz 2002; Gao and Smyth 2011; Arampatzi et al. 2020). Theoretically, it could be argued that this might not be the case for hope, since hope is focused more on the process of goal-attainment, and is inherently imbued with uncertainty. Therefore, we could expect to find diminishing returns on SWB from expectations but not from hope. To test this hypothesis, we ran two fixed effects regression models including a quadratic transformation of hope and expectations and plotted the predicted values for life satisfaction against hope and expectations.

As can be seen in Fig. 1, hope displays a quite clear linear relation with life satisfaction; each additional point of hope translates in a relatively similar increase in life satisfaction. The same seems to apply to expectations. Although the difference between expecting changes for worse and expecting things to stay the same is slightly bigger than that between expecting no changes and expecting improvements (a score of 5.58, 6.23 and 6.80 respectively), this difference is too small to assume nonlinearity. Moreover, both quadratic 
transformations of hope and expectations were insignificant. These results suggest that both hope and expectations have a relatively linear relation to SWB and raise no indications that being too hopeful is actually harmful for our wellbeing due to disappointment.

\section{Discussion}

This study aimed to elucidate the mechanisms through which income increases SWB. In particular, we investigated whether an increase in income makes us happier because it makes us feel more hopeful about the future. The results indicate that income does indeed go hand-in-hand with more hope, and that this increased hope most likely explains part of the positive effect of income on SWB, but only for household-incomes over $\$ 1,800$ a month. Increases to an income below this amount do not seem to translate into higher hopes. This could indicate that attaining a certain threshold of income is necessary in order to influence our hopefulness. This might be explained by the (lack of) capabilities that an income below $\$ 1800$ can offer. The poverty threshold in the US in 2018 ranged between \$1089; \$1407 and \$1684 for single households; two-person households without; or with children respectively (United States Census Bureau 2019). Since the highest income-category for which we find no relation with hope ranges from $\$ 1300$ to $\$ 1800$ and the majority of the sample consists of households with more than one person, we can conclude that a large portion of people for whom we do not find a relation between income and hope, are living around or below the poverty threshold. For these people, an increase in income will still not allow them to rise above a situation of 'making ends meet'. More specifically, in these contexts it is still impossible to make the meaningful investments in a better future, that would allow for a more hopeful disposition. This is however not the case for expectations; each increase in income translates into more positive expectations for our future standard of living. This thus also indicates that having hope and having expectations relate to different concepts; while the former comprises the desire for an uncertain, positive future, the second encompasses an estimation of the likelihood that things will get better, regardless of whether we think about it and desire it (Day 1969).

The component of agency, the assumption that we can achieve what we want in life, appears to be a stronger mediator than pathways, the resourcefulness in coming up with ways to achieve our goals. This appears to be because agency is more strongly related to both income and life satisfaction. Having money thus mainly allows us to believe we can achieve what we want, which in turn goes together with greater life satisfaction. Being resourceful in coming up with different routes towards our goals may be equally important for actual goal-pursuit but is less important in our perception of life. Hope furthermore plays a mediating role for two components of SWB, namely life satisfaction and happiness. In this study we find no relation between income and affect, which might indicate that income mainly raises our global judgment of life (i.e. life satisfaction), but not so much the specific emotions we experience on a day-to-day basis (i.e. emotional wellbeing).

Previous research is somewhat ambiguous about the question whether more hope or optimism is always good for our wellbeing. Although moderate optimism is generally regarded as positive, several thinkers warn against the possible negative effects of overly excited expectations due to disappointment, indicating that there might be diminishing returns on the relation between optimism and SWB, and the same could be expected of hope. In this study, however, we find no indications that this is the case; the relation between both hope and expectations with SWB appears to be stable and linear. With 
regards to hope, this finding was expected, but with regard to expectations it was not. There are several possible explanations for our findings. Firstly, it could be due to the relatively small sample in this study and because our expectations-question has only three answering-categories. Second, it could be the case that previously found 'disappointment effects' of overly enthusiastic expectations are mainly at play during times of societal turmoil, such as during an economic crisis (Arampatzi et al. 2020) or rapid economic development (Gao and Smyth 2011). In such instances, expectations might more easily be disappointed due to the great volatility of societal change. In this study, however, we are following a group of people who live in a relatively stable context and might thus not experience such dramatic changes in expectations. Third, and related to the former point, the finding might be due to our methods of analysis. A fixed effects model focuses on changes within an individual, rather than on levels at a certain point in time. Hence, it could be the case that although having an extremely high level of expectations will result in disappointment, improving your expectations from for example very low to moderate will have a much more positive effect on SWB.

There are several limitations to this study. First and foremost; although we are able to control for time-invariant characteristics such as personality by studying how people change over time, we might have omitted important time-variant variables that affect both income, hope and life satisfaction (for example societal crises or unemployment rates). Also, in this study we measured life satisfaction, overall happiness and expectations using single-item questions, which, although shown to have acceptable validity (Cheung and Lucas 2014; Schimmack and Oishi 2005), might yield different results compared to multiitems scales measuring SWB, such as the Satisfaction With Life Scale (Diener et al. 1985). Moreover, our sample seems to differ from the U.S. population on some of the main variables of this study, namely life satisfaction, expectations and income. In general, it appears that this sample is less satisfied and optimistic about the future, although the scores for hope are within the range of what could be expected. Moreover, since our income categories do not capture the US income distribution all that well, we have little information on how this mediating mechanism would work for the higher parts of the income distribution. However, a sensitivity analysis with only the two waves that have consistent information on higher income categories, indicates that the mediating relation of hope between income and life satisfaction also applies to these higher income categories. Overall, however, we still have to be very careful at extrapolating these findings to the U.S. at large. Furthermore, we cannot infer causality from our analyses; that is, we cannot claim with certainty that income causes us to be more hopeful, and that hope in turn is responsible for the changes in life satisfaction. All relations in our analyses could run in both directions, for example because hopeful people more easily find high paying jobs, or when happy persons become more hopeful. This could lead us to overestimate the real impact of the studied relations. Moreover, since the changes in our variables over time are relatively small, we can only make cautious claims based on our findings. However, the mediating role of hope in the relation between income and life satisfaction appears to be robust to changing methods and instruments, strengthening the credibility of our claims.

The findings of this study contribute to existing knowledge in several ways. First, by showing that hope is responsible for at least part of the relation between income and SWB, we can better predict in which circumstances higher income will have a meaningful influence on our wellbeing. That is, increased income might not have as much of an impact on our lives if it does not bring with it a sense of security and improved future prospects. This might for example be an important consideration when comparing the pros and cons of short-term contracts compared to longer-term employment-contracts. More generally, we 
find a robust and quite strong correlation between hope and life satisfaction, even when controlling for objective life-circumstances, indicating that hope really matters for our wellbeing. This would imply that people who lose hope, either because of low income, feelings of unsafety or lack of opportunities, are markedly less satisfied with their lives, with all its subsequent consequences (DeNeve et al. 2013). Second, by understanding the importance of the 'sustainability' of our income, i.e. the feeling that our future will be brighter because of it, we can better explain the apparent paradox of the relatively limited predictive power of income on happiness, the so-called 'Easterlin Paradox' (Easterlin 1973; Diener et al. 2013). Income might not increase SWB as much as expected partly because it does not always improve our perspectives on the future. Third, by investigating the linearity of the relation of SWB with hope and expectations, we can better understand when positive perspectives of the future translate into higher SWB. Although future research is necessary to study the potential 'disappointment effects' of extremely optimistic views of the future in more detail and in different contexts, we find no evidence that being either too hopeful or having very high expectations is harmful for wellbeing. This indicates that attention to the important human emotion of hope could greatly improve our understanding of what makes us enjoy our lives.

\section{Conclusion}

In conclusion, hope does seem to partially mediate the relation between income and SWB, measured either as happiness or as life satisfaction. This is the case for people with a middle to higher income, while expectations mediate the relation for all levels of income. In addition, we do not find evidence for diminishing returns on the relation between hope and expectations with SWB, signaling there is no or only a limited disappointment effect of being overly optimistic. For economists and other scholars interested in studying the effects of people's perception of the future on wellbeing, hope might be an interesting topic of research. Our findings signal that policy aimed at increasing wellbeing through higher wages should take into account that the stability of income matters, and that only over a certain threshold income can offer enough possibilities to invest in a better future and as such create more hopeful and happy lives. Future research could focus on the specific conditions under which income does engender hope for the future, specifically by conducting larger-scale panel analyses and by studying the causality of these relations through experiments. Moreover, more elaborate examinations of the relation between expectation and wellbeing could investigate if and under which circumstances overly optimistic expectations might diminish wellbeing through disappointment.

Funding Martijn Burger and Emma Pleeging received financial support from the Goldschmeding Foundation for People, Work and Economy (project 'Hope as an Incentive'). The Internal Review Board of the Erasmus School of Health Policy \& Management at the Erasmus University Rotterdam has reviewed this study and declares that the study procedures meet the standards for ensuring ethical treatment of respondents (Reference: IRB 20-20 Pleeging).

\section{Compliance with Ethical Standards}

Conflicts of interest Job van Exel declares that he has no conflicts of interest. 
Open Access This article is licensed under a Creative Commons Attribution 4.0 International License, which permits use, sharing, adaptation, distribution and reproduction in any medium or format, as long as you give appropriate credit to the original author(s) and the source, provide a link to the Creative Commons licence, and indicate if changes were made. The images or other third party material in this article are included in the article's Creative Commons licence, unless indicated otherwise in a credit line to the material. If material is not included in the article's Creative Commons licence and your intended use is not permitted by statutory regulation or exceeds the permitted use, you will need to obtain permission directly from the copyright holder. To view a copy of this licence, visit http://creativecommons.org/licenses/by/4.0/.

\section{Appendix A: Full List of Items for the Adult Trait Hope Scale}

1. I can think of many ways to get out of a jam.

2. I energetically pursue my goals.

3. I feel tired most of the time.

4. There are lots of ways around any problem.

5. I am easily downed in an argument.

6. I can think of many ways to get the things in life that are important to me.

7. I worry about my health.

8. Even when others get discouraged, I know I can find a way to solve the problem.

9. My past experiences have prepared me well for my future.

10. I've been pretty successful in life.

11. I usually find myself worrying about something.

12. I meet the goals that I set for myself.

Items $2,9,10$, and 12 make up the agency subscale.

Items $1,4,6$, and 8 make up the pathway subscale.

Items $3,5,7$, and 11 are fillers.

\section{Appendix B: Different Scores on Main Variables Over the Years}

See Table 8.

See Table 9.

See Table 10. 
Table 8 ANOVA between respondents who participated 1 , 2 or 3 years

Table $9 \mathrm{Chi}^{2}$ test on the relation between income and participating multiple years

\begin{tabular}{lccc}
\hline & One year & Two years & Three years \\
\hline Life satisfaction & 6.34 & 6.46 & 6.16 \\
One year & & & -0.18 \\
& & $(1.00)$ \\
Two years & 0.12 & & -0.30 \\
& $(1.00)$ & & $(0.24)$ \\
Hope & 4.71 & 4.95 & 4.97 \\
One year & & & 0.26 \\
& & & $(0.02)$ \\
Two years & $0.24^{\mathrm{a}}$ & & 0.02 \\
& $(0.07)$ & & $(1.00)$ \\
\hline
\end{tabular}

p-level in parenthesis

${ }^{\text {a }}$ Significant at the 0.1 level

${ }^{\mathrm{b}}$ Significant the 0.05 level

${ }^{\mathrm{c}}$ Significant at the 0.01 level

\begin{tabular}{lccc}
\hline & One year $(\%)$ & Two years $(\%)$ & $\begin{array}{l}\text { Three } \\
\text { years } \\
(\%)\end{array}$ \\
\hline Less than $\$ 900$ & 6 & 4 & 8 \\
$\$ 900-\$ 1300$ & 9 & 13 & 9 \\
$\$ 1300-\$ 1800$ & 13 & 18 & 9 \\
$\$ 1800-\$ 2700$ & 29 & 22 & 27 \\
$\$ 2700-\$ 3200$ & 15 & 17 & 15 \\
More than $\$ 3200$ & 27 & 26 & 32 \\
Pearson chi ${ }^{2}(10)=9.78$ Pr $=0.46$ & & \\
\hline
\end{tabular}


Table 10 Testing selection effects based on personal characteristics for participating in multiple waves

\begin{tabular}{|c|c|c|c|}
\hline & One year only & Two years & Three years \\
\hline Age & 30.8 & 29.7 & 37.3 \\
\hline One year & & & $\begin{array}{l}6.42^{\mathrm{c}} \\
(0.00)\end{array}$ \\
\hline Two years & $\begin{array}{l}-1.19 \\
(0.87)\end{array}$ & & $\begin{array}{l}7.61^{\mathrm{c}} \\
(0.00)\end{array}$ \\
\hline \multicolumn{4}{|l|}{ Gender } \\
\hline Male & $63 \%$ & $56 \%$ & $55 \%$ \\
\hline Female & $37 \%$ & $44 \%$ & $45 \%$ \\
\hline \multicolumn{4}{|c|}{ Pearson $\operatorname{chi}^{2}(2)=2.96 \operatorname{Pr}=0.23$} \\
\hline \multicolumn{4}{|l|}{ Household composition } \\
\hline Single & $46 \%$ & $45 \%$ & $42 \%$ \\
\hline Single parent & $4 \%$ & $7 \%$ & $5 \%$ \\
\hline Couple without children & $20 \%$ & $23 \%$ & $23 \%$ \\
\hline Couple with children & $24 \%$ & $19 \%$ & $23 \%$ \\
\hline Other & $6 \%$ & $7 \%$ & $6 \%$ \\
\hline \multicolumn{4}{|c|}{ Pearson $\operatorname{chi}^{2}(8)=3.23 \mathrm{Pr}=0.92$} \\
\hline \multicolumn{4}{|l|}{ Ethnicity } \\
\hline White & $73 \%$ & $69 \%$ & $77 \%$ \\
\hline Black/African American & $12 \%$ & $10 \%$ & $7 \%$ \\
\hline Asian & $8 \%$ & $7 \%$ & $5 \%$ \\
\hline Other & $7 \%$ & $13 \%$ & $11 \%$ \\
\hline \multicolumn{4}{|c|}{ Pearson $\operatorname{chi}^{2}(6)=7.35 \mathrm{Pr}=0.29$} \\
\hline \multicolumn{4}{|l|}{ Religion } \\
\hline Very important & $9 \%$ & $8 \%$ & $12 \%$ \\
\hline Important & $18 \%$ & $13 \%$ & $12 \%$ \\
\hline Slightly important & $26 \%$ & $15 \%$ & $17 \%$ \\
\hline Not at all important & $47 \%$ & $64 \%$ & $59 \%$ \\
\hline \multicolumn{4}{|c|}{ Pearson $\operatorname{chi}^{2}(6)=15.13 \operatorname{Pr}=0.02$} \\
\hline
\end{tabular}

p-level in parenthesis

${ }^{\text {a }}$ Significant at the 0.1 level

${ }^{\mathrm{b}}$ Significant the 0.05 level

${ }^{\mathrm{c}}$ Significant at the 0.01 level

\section{Appendix C: Mediation Analysis on the Relation Between Income and Affect}

See Table 11. 
Table 11 Fixed effects regression model on affect and hope

\begin{tabular}{|c|c|c|c|c|}
\hline & $\begin{array}{l}(1) \\
\text { Affect }\end{array}$ & $\begin{array}{l}(2) \\
\text { Affect }\end{array}$ & $\begin{array}{l}(1-2) \\
\text { Difference }\end{array}$ & $\begin{array}{l}(3) \\
\text { Affect }\end{array}$ \\
\hline \multicolumn{5}{|l|}{ Income } \\
\hline$<\$ 900$ & Reference & Reference & & \\
\hline$\$ 900-\$ 1300$ & $\begin{array}{l}0.193 \\
0.182)\end{array}$ & $\begin{array}{l}0.141 \\
(0.164)\end{array}$ & 0.052 & \\
\hline$\$ 1300-\$ 1800$ & $\begin{array}{l}0.152 \\
(0.177)\end{array}$ & $\begin{array}{l}0.073 \\
(0.159)\end{array}$ & 0.079 & \\
\hline$\$ 1800-\$ 2700$ & $\begin{array}{l}0.171 \\
(0.181)\end{array}$ & $\begin{array}{l}0.026 \\
(0.164)\end{array}$ & $0.145^{\mathrm{a}}$ & \\
\hline$\$ 2700-\$ 3200$ & $\begin{array}{l}0.289 \\
(0.185)\end{array}$ & $\begin{array}{l}0.136 \\
(0.167)\end{array}$ & $0.153^{\mathrm{a}}$ & \\
\hline More than $\$ 3200$ & $\begin{array}{l}0.326^{\mathrm{a}} \\
(0.189)\end{array}$ & $\begin{array}{l}0.089 \\
(0.173)\end{array}$ & $0.237^{\mathrm{c}}$ & \\
\hline Hope & & $\begin{array}{l}0.607^{\mathrm{c}} \\
(0.054)\end{array}$ & & $\begin{array}{l}0.610^{\mathrm{c}} \\
(0.049)\end{array}$ \\
\hline Constant & $\begin{array}{l}6.608^{c} \\
(1.459)\end{array}$ & $\begin{array}{l}3.477^{c} \\
(1.341)\end{array}$ & & $\begin{array}{l}3.502^{\mathrm{c}} \\
(1.233)\end{array}$ \\
\hline $\mathrm{R}^{2}$ (within) & 0.128 & 0.430 & & 0.444 \\
\hline$N$ (groups) & 327 & 327 & & 339 \\
\hline
\end{tabular}

Robust standard errors in parenthesis

All models are corrected for age, age squared, gender, household composition and year-dummies

${ }^{\text {a }}$ Significant at the 0.1 level

${ }^{\mathrm{b}}$ Significant the 0.05 level

${ }^{\mathrm{c}}$ significant at the 0.01 level

\section{References}

Abdel-Khalek, A. M. (2006). Measuring happiness with a single-item scale. Social Behavior and Personality: An international journal, 34(2), 139-150.

Aghababaei, N., Sohrabi, F., Eskandari, H., Borjali, A., Farrokhi, N., \& Chen, Z. J. (2016). Predicting subjective well-being by religious and scientific attitudes with hope, purpose in life, and death anxiety as mediators. Personality and Individual Differences, 90, 93-98.

Alarcon, G. M., Bowling, N. A., \& Khazon, S. (2013). Great expectations: A meta-analytic examination of optimism and hope. Personality and Individual Differences, 54(7), 821-827.

Arampatzi, E., Burger, M. J., \& Veenhoven, R. (2015). Financial Distress and Happiness of Employees in Times of Economic Crisis. Applied Economic Letters, 22(3), 173-179.

Arampatzi, E., Burger, M. J., Stavropoulos, S., \& Tay, L. (2020). The role of positive expectations for resilience to adverse events: Subjective well-being before, during and after the greek bailout referendum. Journal of Happiness Studies, 21(3), 965-995.

Averill, J. R., Catlin, G., \& Chon, K. K. (1990). Rules of hope. NY: Springer.

Bailey, T. C., Eng, W., Frisch, M. B., \& Snyder, C. R. (2007). Hope and optimism as related to life satisfaction. The Journal of Positive Psychology, 2(3), 168-175.

Bailey, T. C., \& Snyder, C. R. (2007). Satisfaction with life and hope: A look at age and marital status. The Psychological Record, 57(2), 233-240.

Banerjee, A., Duflo, E., Goldberg, N., Karlan, D., Osei, R., Parienté, W., et al. (2015). A multifaceted program causes lasting progress for the very poor: Evidence from six countries. Science, 348(6236), 1260799.

Bell, D. E. (1985). Disappointment in decision making under uncertainty. Operations Research, 33(1), 1-27. 
Belle, D., \& Doucet, J. (2003). Poverty, inequality, and discrimination as sources of depression among US women. Psychology of Women Quarterly, 27(2), 101-113.

Blake, J., Brooks, J., Greenbaum, H., \& Chan, F. (2017). Attachment and employment outcomes for people with spinal cord injury: The intermediary role of hope. Rehabilitation Counseling Bulletin, 60(2), 77-87.

Brown, S., Taylor, K., \& Price, S. W. (2005). Debt and distress: Evaluating the psychological cost of credit. Journal of Economic Psychology, 26(5), 642-663.

Cheung, F. (2016). Can income inequality be associated with positive outcomes? hope mediates the positive inequality-happiness link in rural china. Social Psychological and Personality Science, 7(4), 320-330.

Cheung, F., \& Lucas, R. E. (2014). Assessing the validity of single-item life satisfaction measures: Results from three large samples. Quality of Life research, 23(10), 2809-2818.

Ciarrochi, J., Parker, P., Kashdan, T. B., Heaven, P. C. L., \& Barkus, E. (2015). Hope and emotional wellbeing: A six year study to distinguish antecedents, correlates, and consequences. The Journal of Positive Psychology, 10(6), 520-532.

Clark, A. E., Frijters, P., \& Shields, M. A. (2008). Relative income, happiness, and utility: An explanation for the easterlin paradox and other puzzles. Journal of Economic literature, 46(1), 95-144.

Cotton Bronk, K., Hill, P. L., Lapsley, D. K., Talib, T. L., \& Finch, H. (2009). Purpose, Hope, and Life Satisfaction in Three Age Groups. The Journal of Positive Psychology, 4(6), 500-510.

Dalton, P. S., Ghosal, S., \& Mani, A. (2015). Poverty and aspirations failure. The Economic Journal, 126(590), 165-188.

Day, J. P. (1969). Hope. American Philosophical Quarterly, 6(2), 89-102.

De Neve, J. E., Diener, E., Tay, L., \& Xuereb, C. (2013). The objective benefits of subjective well-being. In J. Helliwell, R. Layard, \& J. Sachs (Eds.), World Happiness Report 2013 (pp. 54-79). New York: UN Sustainable Development Solutions Network.

Diener, E. D., Emmons, R. A., Larsen, R. J., \& Griffin, S. (1985). The satisfaction with life scale. Journal of Personality Assessment, 49(1), 71-75.

Diener, E., Suh, E. M., Lucas, R. E., \& Smith, H. L. (1999). Subjective well-being: Three decades of progress. Psychological Bulletin, 125(2), 276-302.

Diener, E., Ng, W., Harter, J., \& Arora, R. (2010). Wealth and happiness across the world: Material prosperity predicts life evaluation, whereas prosperity predicts positive feelings. Journal of Personality and Social Psychology, 99(1), 52-61.

Diener, E., Tay, L., \& Oishi, S. (2013). Rising income and the subjective well-being of nations. Journal of Personality and Social Psychology, 104(2), 267-276.

Downey, G., \& Moen, P. (1987). Personal efficacy, income, and family transitions: A longitudinal study of women heading households. Journal of Health and Social Behavior, 28(3), 320-333.

Du, H., \& King, R. B. (2013). Placing hope in self and others: Exploring the relationships among self-construals, locus of hope, and adjustment. Personality and Individual Differences, 54(3), 332-337.

Duflo, E. (2012). Lack of hope and the persistence of poverty. Marshall Lecture Series.

Easterlin, R. A. (1973). Does money buy happiness? The Public Interest, 30, 3-10.

Easterlin, R. A. (1995). Will raising the incomes of all increase the happiness of all? Journal of Economic Behavior \& Organization, 27(1), 35-47.

Easterlin, R. A. (2001). Income and happiness: Towards a unified theory. The Economic Journal, 111(473), $465-484$.

Ekici, T., \& Koydemir, S. (2016). Income expectations and happiness: Evidence from British panel data. Applied Research in Quality of Life, 11(2), 539-552.

Erikson, E. H. (1950). Childhood and society. New York: Norton.

Foster, G., \& Frijters, P. (2014). The formation of expectations: Competing theories and new evidence. Journal of Behavioral and Experimental Economics, 53, 66-81.

Foster, G., Frijters, P., \& Johnston, D. W. (2012). The triumph of hope over disappointment: A note on the utility value of good health expectations. Journal of Economic Psychology, 33(1), 206-214.

Fredrickson, B. L. (2001). The role of positive emotions in positive psychology: The broaden-and-build theory of positive emotions. American psychologist, 56(3), 218-226.

Frey, B. S., \& Stutzer, A. (2002). What can economists learn from happiness research? Journal of Economic literature, 40(2), 402-435.

Frijters, P., Liu, A. Y. C., \& Meng, X. (2012). Are optimistic expectations keeping the Chinese happy? Journal of Economic Behavior \& Organization, 81(1), 159-171.

Gao, W., \& Smyth, R. (2011). What keeps China's migrant workers going? Expectations and happiness among China's floating population. Journal of the Asia Pacific Economy, 16(2), 163-182.

Gollier, C., \& Muermann, A. (2010). Optimal choice and beliefs with ex ante savoring and ex post disappointment. Management Science, 56(8), 1272-1284. 
Green, F. (2011). Unpacking the misery multiplier: How employability modifies the impacts of unemployment and job insecurity on life satisfaction and mental health. Journal of Health Economics, 30(2), $265-276$.

Greenaway, K. H., Frye, M., \& Cruwys, T. (2015). When aspirations exceed expectations: Quixotic hope increases depression among students. PLOS ONE, 10(9), e0135477.

Halama, P. (2010). Hope as a mediator between personality traits and life satisfaction. Studia Psychologica, 52(4), 309-314.

Hanson, S. L. (1994). Lost talent: Unrealized educational aspirations and expectations among US youths. Sociology of Education, 67(3), 159-183.

Helliwell, J., Layard, R., \& Sachs, J. (2019). World Happiness Report 2019. New York: Sustainable Development Solutions Network.

Herth, K. R. N. (1991). Development and refinement of an instrument to measure hope. Research and Theory for Nursing Practice, 5(1), 39-51.

Jebb, A. T., Tay, L., Diener, E., \& Oishi, S. (2018). Happiness, income satiation and turning points around the world. Nature Human Behaviour, 2(1), 33-38.

Kahneman, D., \& Deaton, A. (2010). High income improves evaluation of life but not emotional well-being. Proceedings of the national academy of sciences, 107(38), 16489-16493.

Krafft, A. M., Martin-Krumm, C., \& Fenouillet, F. (2019). Adaptation, further elaboration, and validation of a scale to measure hope as perceived by people: Discriminant value and predictive utility vis-à-vis dispositional hope. Assessment, 26(8), 1594-1609.

Kushlev, K., Dunn, E. W., \& Lucas, R. E. (2015). Higher income is associated with less daily sadness but not more daily happiness. Social Psychological and Personality Science, 6(5), 483-489.

Lee, S. Y., Florida, R., \& Acs, Z. (2004). Creativity and entrepreneurship: a regional analysis of new firm formation. Regional Studies, 38(8), 879-891.

Loewenstein, G. (1987). Anticipation and the valuation of delayed consumption. The Economic Journal, 97(387), 666-684.

Lopez, S. J., Ciarlelli, R., Coffman, L., Stone, M., \& Wyatt, L. (2000). Diagnosing for strengths: on measuring hope building blocks. In C. R. Snyder (Ed.), Handbook of Hope Theory, Measures and Applications (pp. 57-85). San Diego: Academic Press.

Luhmann, M., Hawkley, L. C., Eid, M., \& Cacioppo, J. T. (2012). Time frames and the distinction between affective and cognitive well-being. Journal of Research in Personality, 46(4), 431-441.

Lybbert, T. J., \& Wydick, B. (2018). Poverty, aspirations, and the economics of hope. Economic Development and Cultural Change, 66(4), 709-753.

Magnano, P., Di Nuovo, S., Scioli, A., \& Di Corrado, D. (2019). A study of the comprehensive hope scale in Italian. TPM Testing Psychometrics Methodology in Applied Psychology, 26(2), 287-304.

Marcel, G. (2010). Homo Viator: Introduction to the Metaphysic of Hope. South Bend: St. Augustine's Press.

Martin, A. M. (2011). Hopes and dreams. Philosophy and Phenomenological Research LXXXII, I(1), $148-173$.

Norman, J. (2017). Americans' Ratings of Standard of Living Best in Decade. Gallup. Retrieved June 4, 2020, from https://news.gallup.com/poll/218981/americans-ratings-standard-living-best-decade.aspx.

O’Connor, K. J., \& Graham, C. (2019). Longer, more optimistic, lives: Historic optimism and life expectancy in the United States. Journal of Economic Behavior \& Organization, 168, 374-392.

Okulicz-Kozaryn, A. (2010). Religiosity and life satisfaction across nations. Mental Health, Religion \& Culture, $13(2), 155-169$.

OECD. (2013). OECD Guidelines on Measuring Subjective Well-being. Paris: OECD Publishing. https:// doi.org/10.1787/9789264191655-en.

Ong, A., Edwards, L. M., \& Bergeman, C. S. (2006). Hope as a source of resilience in later adulthood. Personality and Individual Differences, 41(7), 1263-1273.

Peer, E., Brandimarte, L., Samat, S., \& Acquisti, A. (2017). Beyond the Turk: Alternative platforms for crowdsourcing behavioral research. Journal of Experimental Social Psychology, 70, 153-163.

Pleeging, E., Burger, M., \& van Exel, J. (2019). The relations between hope and subjective well-being: A literature overview and empirical analysis. Applied Research in Quality of Life. https://doi.org/10.1007/ s11482-019-09802-4.

Rustøen, T., Cooper, B., \& Miaskowski, C. (2010). The importance of hope as a mediator of psychological distress and life satisfaction in a community sample of cancer patients. Cancer Nursing, 33(4), 258-267.

Santiago, C. D., Wadsworth, M. E., \& Stump, J. (2011). Socioeconomic status, neighborhood disadvantage, age squared, and poverty-related stress: Prospective effects on psychological syndromes among diverse low-income families. Journal of Economic Psychology, 32(2), 218-230. 
Satici, S. A. (2016). Psychological vulnerability, resilience, and subjective well-being: The mediating role of hope. Personality and Individual Differences, 102, 68-73.

Scheier, M. F., \& Carver, C. S. (1992). Effects of optimism on psychological and physical well-being: Theoretical overview and empirical update. Cognitive Therapy and Research, 16(2), 201-228.

Schimmack, U., \& Oichi, S. (2005). The influence of chronically and temporarily accessible information on life satisfaction judgments. Journal of Personality and Social Psychology, 89(3), 395-406.

Schrank, B., Woppmann Mag, A., Sibitz, I., \& Lauber, C. (2010). Development and validation of an integrative scale to assess hope. Health Expectations, 14(4), 417-428.

Schwartz, A. (2002). Expected feelings about risky options. In S. Moore \& M. Oaksford (Eds.), Emotional Cognition. From brain to behaviour (pp. 183-196). Amsterdam/Philadelphia: John Benjamins Publishing Company.

Scioli, A., Ricci, M., Nguyen, T., \& Scioli, E. R. (2011). Hope: Its nature and measurement. Psychology of Religion and Spirituality, 3(2), 78-97.

Scitovsky, T. (1978). The Joyless Economy. Oxford, United Kingdom: Oxford University Press.

Senik, C. (2008). Is man doomed to progress? Journal of Economic Behavior \& Organization, 68(1), $140-152$.

Sheehan, K. B. (2017). Crowdsourcing research: Data collection with Amazon's Mechanical Turk. Communication Monographs, 85(1), 140-156.

Shorey, H. S., Snyder, C. R., Yang, X., \& Lewin, M. R. (2003). The role of hope as a mediator in recollected parenting, adult attachment, and mental health. Journal of Social and Clinical Psychology, 22(6), 685-715.

Snyder, C. R. (2000). The past and possible futures of hope. Journal of Social and Clinical Psychology, $19(1), 11-28$.

Snyder, C. R., Harris, C., Anderson, J. R., Holleran, S. A., Irving, L. M., Sigmon, S. T., et al. (1991). The will and the ways: Development and validation of an individual-differences measure of hope. Journal of Personality and Social Psychology, 60(4), 570-585.

Squalli, J., \& Wilson, K. (2014). Intelligence, creativity, and innovation. Intelligence, 46, 250-257.

Stevenson, B., \& Wolfers, J. (2013). Subjective well-being and income: Is there any evidence of satiation? American Economic Review, 103(3), 598-604.

Stotland, E. (1969). The Psychology of Hope. San Francisco: Jossey-Bass.

Stutzer, A. (2004). The role of income aspirations in individual happiness. Journal of Economic Behavior \& Organization, 54(1), 89-109.

Sweeney, K., Carroll, P. J. C., \& Shepperd, J. A. (2006). Is optimism always best? future outlooks and preparedness. Current Directions in Psychological Science, 15(6), 302-306.

Tay, L., Batz, C., Parrigon, S., \& Kuykendall, L. (2017). Debt and subjective well-being: The other side of the income-happiness coin. Journal of Happiness Studies, 18(3), 903-937.

Tongchaiprasit, P., \& Ariyabuddhiphongs, V. (2016). Creativity and turnover intention among hotel chefs: The mediating effects of job satisfaction and job stress. International Journal of Hospitality Management, 55, 33-40.

Tversky, A., \& Kahneman, D. (1979). Prospect theory: An analysis of decision under risk. Econometrica, 47(2), 263-291.

U.S. Census Bureau (2017). Income and Poverty in the United States: 2016. Retrieved June 5, 2020, from https://www.census.gov/data/tables/2017/demo/income-poverty/p60-259.html.

United States Census Bureau (2019). Income and Poverty in the United States: 2018. Retrieved June 5, 2020, from https://www.census.gov/data/tables/2019/demo/income-poverty/p60-266.html.

Van Praag, B. M., \& Kapteyn, A. (1973). Further evidence on the individual welfare function of income: An empirical investigation in The Netherlands. European Economic Review, 4(1), 33-62.

Van Praag, B. M., Van Praag, B., \& Ferrer-i-Carbonell, A. (2004). Happiness quantified: A satisfaction calculus approach. Oxford: Oxford University Press.

Veenhoven, R. (2011). Happiness: Also known as 'life satisfaction' and 'subjective well-being'. In K. C. Land, A. C. Michalos, \& M. J. Sirgy (Eds.), Handbook of Social Indicators and Quality of Life Research (pp. 63-77). Berlin: Springer.

Veenhoven, R. (2018). Happiness in United States of America (USA), World Database of Happiness, Erasmus University Rotterdam, The Netherlands. Viewed on 2018-08-26 at https://worlddatabaseofhappi ness.eur.nl.

Ward, S. J., \& King, L. A. (2019). Exploring the place of financial status in the good life: Income and meaning in life. The Journal of Positive Psychology, 14(3), 312-323.

Watson, D., Clark, L. A., \& Tellegen, A. (1988). Development and validation of brief measures of positive and negative affect: The PANAS scales. Journal of Personality and Social Psychology, 54(6), 1063-1070. 
Webb, D. (2007). Modes of Hoping. History of the Human Sciences, 20(3), 65-83.

Wnuk, M., \& Marcinkowski, J. T. (2014). Do existential variables mediate between religious-spiritual facets of functionality and psychological wellbeing. Journal of Religion and Health, 53(1), 56-67.

Yalçın, İ., \& Malkoç, A. (2015). The relationship between meaning in life and subjective well-being: Forgiveness and hope as mediators. Journal of Happiness Studies, 16(4), 915-929.

Yang, Y., Zhang, M., \& Kou, Y. (2016). Self-compassion and life satisfaction: The mediating role of hope. Personality and Individual Differences, 98, 91-95.

Yu, Z., \& Chen, L. (2016). Income and well-being: relative income and absolute income weaken negative emotion, but only relative income improves positive emotion. Frontiers in Psychology, 7, 2012.

Publisher's Note Springer Nature remains neutral with regard to jurisdictional claims in published maps and institutional affiliations. 